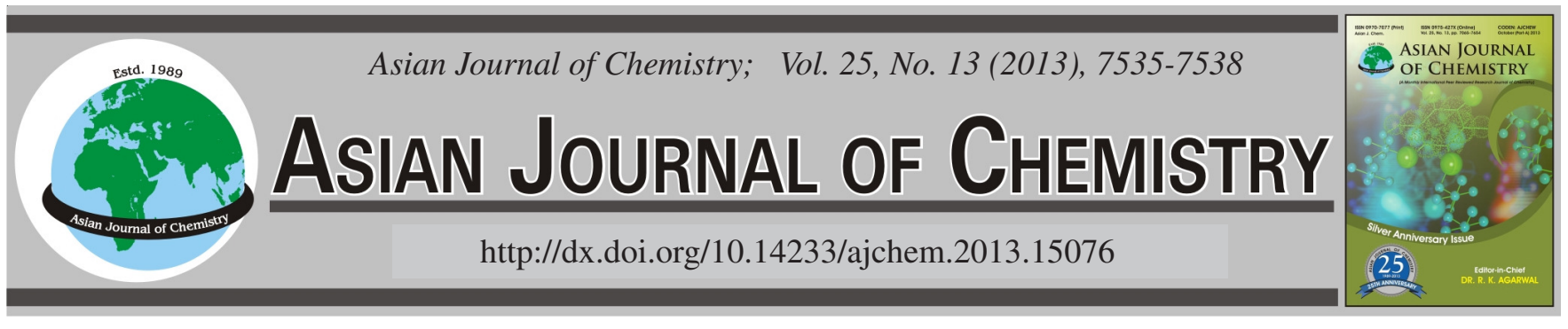

\title{
Cupric Nitrate Catalyzed Efficient and Facile Synthesis of 1,8-Dioxo-octahydroxanthene Derivatives
}

\section{AAYESHA NASREEN}

Department of Chemistry, College of Sciences, Jazan University, 6811-Arroudah, Jazan 82724-3750, P.O. Box No. 2097, Kingdom of Saudi Arabia Corresponding author: Fax: +966 073227066; E-mail: aayesha_iict@yahoo.co.in

An efficient and convenient approach to the synthesis of 1,8-dioxo-octahydroxanthene derivatives by using catalytic amount (10 mol \%) of cupric nitrate $\left[\mathrm{Cu}\left(\mathrm{NO}_{3}\right)_{2} \cdot 3 \mathrm{H}_{2} \mathrm{O}\right]$ in acetonitrile and the yields obtained are in good to excellent (75-96\%). The reaction is highly chemo selective and applicable to aldehydes only.

Key Words: 1,8-Dioxo-octahydroxanthene Derivatives, Acetonitrile, Cupric nitrate, Aldehydes.

\section{INTRODUCTION}

Xanthene derivatives have attracted considerable interest in recent years because of their promising activity as positive allosteric modulators of metabotropic (mGlu) receptors ${ }^{1}$ and potent nonpeptidic inhibitors of recombinant human calpain $\mathrm{I}^{2}$. These have been used as rigid carbon skeletons for the construction of new chiral bidentate phosphine ligands with potential applications in catalytic processes ${ }^{3}$. In particular, xanthenediones constitute a structural unit in a number of natural products ${ }^{4}$ and have been used as versatile synthons because of the inherent reactivity of the inbuilt pyran ring $^{5}$ as well as synthetic derivatives and occupy a prominent position in medicinal chemistry ${ }^{6}$.

The synthesis of xanthenediones usually condenses appropriate active methylene carbonyl compounds with aldehydes catalyzed by sulfuric acid or hydrochloric acid ${ }^{7}$. Vranken et al. $^{8}$ described two-step synthesis of 9-aryl-6hydroxy-3H-xanthen-3-one fluorophores by condensation of aryl aldehydes and fluororesorcinol. Singh et al. ${ }^{9}$ reported a new method for the preparation of xanthenediones through carbon transfer reactions of 1,3-oxazinanes and oxazolidines with carbon nucleophiles.

According to the availability and the economic viability of starting materials, various catalysts such as tetra butyl ammonium hexatungstate $[\mathrm{TBA}]_{2}\left[\mathrm{~W}_{6} \mathrm{O}_{19}\right]^{10}$, tetrabutyl ammonium hydrogen sulphate ${ }^{11}$, samarium chloride ${ }^{12}$, calcium chloride in $\mathrm{DMSO}^{13}, \mathrm{H}_{2} \mathrm{SO}_{4}$ in water ${ }^{14}$, MontK10 ${ }^{15}, \beta$-cyclodextrin ${ }^{16}$, DOWEX-50W ${ }^{17}$, amino alcohol ${ }^{18}$, saccharin sulphonic acid $^{19}$, diethyl ethoxymethylene malonate ${ }^{20}$, Silica supported sodium hydrogen sulphate ${ }^{21}$, N-bromosuccinimide ${ }^{22}$, benzyltriethyl ammonium chloride ${ }^{23}, p$-dodecyl benzenesulfonic acid $^{24}, \mathrm{InCl}_{3} /$ ionic liquid ${ }^{25}$ and $\mathrm{Fe}^{3+}$-mont ${ }^{26}$, have been reported for the synthesis of xanthenedione derivatives. In which some of them often involves the use of expensive reagents, hazard organic solvents and tedious workup.

However, due to their great importance, there still needs to be development of novel methods for the preparation of xanthenediones. With the increasing environmental concerns and the regulatory constraints faced in the chemical and pharmaceutical industries, development of environmentally friendly benign organic reactions has become a crucial and demanding research area in modern organic chemical research ${ }^{27}$. In continuation of our interest in the area of clean synthesis ${ }^{28}$ herein, the synthesis of xanthenediones catalyzed by cupric nitrate in acetonitrile is reported (Scheme-I).

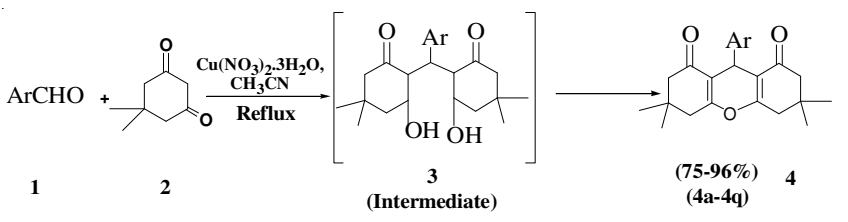

Scheme-I: Synthesis of 1,8-dioxo-octahydroxanthenes catalyzed by $\mathrm{Cu}\left(\mathrm{NO}_{3}\right)_{2} \cdot 3 \mathrm{H}_{2} \mathrm{O}$ in acetonitrile

\section{EXPERIMENTAL}

Chemicals were purchased from Fluka and S.D. Fine chemicals and directly used for the synthesis. Thin layer chromatography (TLC): precoated silica gel plates $\left(60 \mathrm{~F}_{254}\right.$, $0.2 \mathrm{~mm}$ layer; E. Merck). ${ }^{1} \mathrm{H}$ NMR (Avance $300 \mathrm{MHz}$ ) spectra were recorded in $\mathrm{CDCl}_{3}$ using TMS as internal standard. 
Chemical shifts $(\delta)$ are reported in ppm, Melting points (m.p.) were determined on a Fischer-Johns melting point apparatus. IR and MS were recorded on a Thermo Nicolet Nexus 670 FT-IR Spectrometer and Finnegan MAT 1020 Mass spectrometer operating at $70 \mathrm{eV}$.

General procedure: To the stirred solution of $\mathrm{Cu}\left(\mathrm{NO}_{3}\right)_{2} \cdot 3 \mathrm{H}_{2} \mathrm{O}$ in acetonitrile $(5 \mathrm{~mL})$ were added successively 5,5-dimethyl-1,3-cyclohexanedione (dimedone) $(2 \mathrm{mM})$ and benzaldehyde $(1 \mathrm{mM})$ and refluxed for the time specified in (Table-3). After completion of the reaction as indicated by TLC, the reaction mixture was washed with water and extracted into ether dried over anhydrous $\mathrm{Na}_{2} \mathrm{SO}_{4}$ and concentrated under vacuum, the obtained crude product was further purified by column chromatography using EtOAc/hexane (1:9) to afford the white solid of 3,3,6,6-tetramethyl-9-benzene-1,8-dioxooctahydroxanthene is obtained in $96 \%$ yield. All the compounds are known and gave satisfactory spectroscopic data in accordance to the reported data ${ }^{11,21-26}$.

\section{RESULTS AND DISCUSSION}

In continuation of our interest in the development of a highly expedient methodology for the synthesis of fine chemicals like xanthenediones, which constitutes a structural unit in natural products and used as synthons because of the inbuilt pyran ring, we report here for the first time synthesis of 1,8 di-oxo-octahydroxanthene derivatives $\mathbf{4}$ from the conjugate addition of various aldehydes $\mathbf{1}$ and dimedone (5,5-dimethyl1,3-cyclohexanedione) $\mathbf{2}$ in the presence of $\mathrm{Cu}\left(\mathrm{NO}_{3}\right)_{2} \cdot 3 \mathrm{H}_{2} \mathrm{O}$ in acetonitrile at reflux, as an efficient catalyst (Scheme-I).

Initially we have studied the efficacy of several metal nitrates chosen (10 mol \% as standard) for the model reaction using dimedone $(2 \mathrm{mmol})$ and benzaldehyde $(1 \mathrm{mmol})$ in acetonitrile $(5 \mathrm{~mL})$ being refluxed for $7 \mathrm{~h}$ to afford the corresponding 3,3,6,6-tetramethyl-9-aryl1,8-dioxo-octahydroxanthene derivatives and the results are presented in (Table-1). While comparing the effect of catalysts, we found that $\mathrm{Cu}\left(\mathrm{NO}_{3}\right)_{2} \cdot 3 \mathrm{H}_{2} \mathrm{O}$ was more effective than other nitrates tested, in terms of isolated yield (96\%) (Table-1, Entry 7). We choose $\mathrm{Cu}\left(\mathrm{NO}_{3}\right)_{2} \cdot 3 \mathrm{H}_{2} \mathrm{O}$ as the suitable catalyst for further reactions due to its easy availability, cost effectiveness, easy handling, intrigued by these observations, we have then tested the efficacy of several copper salts available such as $\mathrm{Cu}(\mathrm{OAc})_{2}$, $\mathrm{H}_{2} \mathrm{O}, \mathrm{Cu}(\mathrm{Cl}, \mathrm{Br}, \mathrm{I})$ along with $\mathrm{Cu}\left(\mathrm{NO}_{3}\right)_{2} \cdot 3 \mathrm{H}_{2} \mathrm{O}$ for the model reaction and among the copper salts screened $\mathrm{Cu}\left(\mathrm{NO}_{3}\right)_{2} \cdot 3 \mathrm{H}_{2} \mathrm{O}$ was found to be the best both in terms of reaction time and yields.

To examine the influence of effect of various solvents for the model reaction, we also carried out the model reaction in different organic solvents results are shown in (Table-2) and among screened, acetonitrile (96\%) (Entry 5) was found to be the best choice of solvent. An optimum amount of $10 \mathrm{~mol} \%$ of $\mathrm{Cu}\left(\mathrm{NO}_{3}\right)_{2} \cdot 3 \mathrm{H}_{2} \mathrm{O}$ in acetonitrile is sufficient to carry forward the reaction. In the presence of catalyst at room temperature for $24 \mathrm{~h}$ did not yield the product. Encouraged by these results obtained for benzaldehyde we generalized the reaction scope for a number of other structurally divergent aromatic aldehyde and ketones. The reaction with aliphatic and aromatic ketones such as cyclohexanone and acetophenone were found to be

\begin{tabular}{|c|c|c|}
\hline \multicolumn{3}{|c|}{$\begin{array}{c}\text { TABLE-1 } \\
\text { SCREENING OF VARIOUS METAL NITRATES } \\
\text { FOR THE MODEL REACTION }\end{array}$} \\
\hline Entry & Catalyst & Yield (\%) \\
\hline 1 & $\mathrm{Zn}\left(\mathrm{NO}_{3}\right)_{2} \cdot 6 \mathrm{H}_{2} \mathrm{O}$ & 50 \\
\hline 2 & $\mathrm{AgNO}_{3}$ & NR \\
\hline 3 & $\mathrm{Fe}\left(\mathrm{NO}_{3}\right)_{3} \cdot 9 \mathrm{H}_{2} \mathrm{O}$ & 76 \\
\hline 4 & $\mathrm{Rh}\left(\mathrm{NO}_{3}\right)_{3} \cdot 2 \mathrm{H}_{2} \mathrm{O}$ & 65 \\
\hline 5 & $\mathrm{La}\left(\mathrm{NO}_{3}\right)_{3} \cdot 6 \mathrm{H}_{2} \mathrm{O}$ & 70 \\
\hline 6 & $\mathrm{Nd}\left(\mathrm{NO}_{3}\right)_{3} \cdot 6 \mathrm{H}_{2} \mathrm{O}$ & 85 \\
\hline 7 & $\mathrm{Cu}\left(\mathrm{NO}_{3}\right)_{2} \cdot 3 \mathrm{H}_{2} \mathrm{O}$ & 96 \\
\hline 8 & $\mathrm{Ce}\left(\mathrm{NH}_{4}\right)_{2} \cdot\left(\mathrm{NO}_{3}\right)_{6}$ & 40 \\
\hline 9 & $\mathrm{Ni}\left(\mathrm{NO}_{3}\right)_{3} \cdot 6 \mathrm{H}_{2} \mathrm{O}$ & NR \\
\hline 10 & $\mathrm{Bi}\left(\mathrm{NO}_{3}\right)_{3} \cdot 5 \mathrm{H}_{2} \mathrm{O}$ & NR \\
\hline 11 & $\mathrm{Al}\left(\mathrm{NO}_{3}\right)_{3} \cdot 9 \mathrm{H}_{2} \mathrm{O}$ & 45 \\
\hline
\end{tabular}

\begin{tabular}{ccc}
\multicolumn{3}{c}{ TABLE-2 } \\
\multicolumn{3}{c}{$\begin{array}{c}\text { SCREENING OF VARIOUS SOLVENTS } \\
\text { FOR THE MODEL REACTION }\end{array}$} \\
\hline Entry & Solvent & Yield $(\%)^{\mathrm{a}}$ \\
\hline 1 & $\mathrm{DCM}$ & $\mathrm{NR}$ \\
2 & $\mathrm{DMF}$ & 75 \\
3 & $\mathrm{THF}$ & 30 \\
4 & $\mathrm{H}_{2} \mathrm{O}$ & $\mathrm{NR}$ \\
5 & $\mathrm{CH}_{3} \mathrm{CN}$ & 96 \\
6 & $\mathrm{EtOAc}$ & 54 \\
7 & $\mathrm{CHCl}_{3}$ & 50 \\
8 & $\mathrm{DEA}$ & $\mathrm{NR}$ \\
9 & Ethanol & 50 \\
\hline
\end{tabular}

unsuccessful. To study their behaviour under the optimized reaction parameters i.e., $10 \mathrm{~mol} \%$ of $\mathrm{Cu}\left(\mathrm{NO}_{3}\right)_{2} \cdot 3 \mathrm{H}_{2} \mathrm{O}$ in acetonitrile at reflux and summarizes the observations.

The nature of substituent's on aromatic ring showed some effect on this conversion. In general, electron rich counter parts such as hydroxy group, methoxy group, methyl group and so forth required less reaction times, than those of electron withdrawing groups such as (nitro group, halide) were employed and reacted well to give the corresponding, 1,8-dioxo-octahydroxanthene derivatives in good to excellent yields, without undergoing polymerization and isomerisation. There were some limitations for the $\mathrm{Cu}\left(\mathrm{NO}_{3}\right)_{2} \cdot 3 \mathrm{H}_{2} \mathrm{O}$ catalyzed reaction, surprisingly reaction with aliphatic aldehyde does not yield the desired product, instead which gives some by products. The possible mechanism to account for the reaction is Knoevenagel addition between aldehyde and dimedone and subsequently, water elimination of intermediate 3 (SchemeI) resulted in the formation of desired product ${ }^{26}$. Heteroaromatic aldehyde such as pyridine-2-carboxaldehyde survived well without the formation of any side product under the present reaction conditions giving the corresponding 1,8dioxo-octahydroxanthene derivatives in moderate yields. All the products were well characterized (Table-3).

The efficiency and generality of the present cupric nitrate catalyzed protocol can be realized by comparing our result for the reaction of benzaldehyde with dimedone chosen as model substrate with those of some recently developed procedures by comparing with respect to the reaction times-mol \% of the catalyst used and the yields. As it is evident from the previous data, our protocol is comparatively better in terms of 
TABLE-3

SYNTHESIS OF 1,8-DIOXO-OCTAHYDROXANTHENES* CATALYZED BY Cu(NO $\left.{ }_{3}\right)_{2} \cdot 3 \mathrm{H}_{2} \mathrm{O}$ IN ACETONITRILE

\begin{tabular}{|c|c|c|c|c|c|c|c|}
\hline \multirow{2}{*}{ Entry } & \multirow{2}{*}{ Aldehyde } & \multirow{2}{*}{$\tau(\mathrm{h})$} & \multirow{2}{*}{ Product } & \multirow{2}{*}{ Yield (\%) } & \multicolumn{2}{|c|}{ m.p. $\left({ }^{\circ} \mathrm{C}\right)$} & \multirow{2}{*}{ Ref. } \\
\hline & & & & & (Found) & (Reported) & \\
\hline 1 & $\mathrm{C}_{6} \mathrm{H}_{5}$ & 7.0 & $4 a$ & 96 & $203-204$ & 204-205 & $11^{\mathrm{b}}$ \\
\hline 2 & 4- $\mathrm{ClC}_{6} \mathrm{H}_{4}$ & 9.0 & $4 b$ & 89 & $228-231$ & $230-231$ & $11^{\mathrm{b}}$ \\
\hline 3 & $4-\mathrm{HOC}_{6} \mathrm{H}_{4}$ & 7.0 & $4 c$ & 88 & $245-247$ & $246-247$ & $11^{\mathrm{b}}$ \\
\hline 4 & $2-\mathrm{HOC}_{6} \mathrm{H}_{4}$ & 7.0 & 4d & 93 & $203-205$ & $205-206$ & 18 \\
\hline 5 & $3-\mathrm{HOC}_{6} \mathrm{H}_{4}$ & 7.0 & $4 e$ & 81 & $224-226$ & $225-227$ & 26 \\
\hline 6 & $4-\mathrm{HO}-3-\mathrm{CH}_{3} \mathrm{OC}_{6} \mathrm{H}_{3}$ & 7.0 & $4 f$ & 90 & $228-229$ & $226-228$ & 26 \\
\hline 7 & $\mathrm{C}_{6} \mathrm{H}_{5} \mathrm{CH}=\mathrm{CH}$ & 7.0 & $4 g$ & 90 & 176 & $175-177$ & $11^{\mathrm{b}}$ \\
\hline 8 & $2-\mathrm{ClC}_{6} \mathrm{H}_{4}$ & 8.5 & $4 h$ & 94 & 227 & $224-226$ & $11^{\mathrm{b}}$ \\
\hline 9 & $3-\mathrm{NO}_{2} \mathrm{C}_{6} \mathrm{H}_{4}$ & 9.5 & $4 i$ & 91 & $169-170$ & $171-172$ & $11^{\mathrm{b}}$ \\
\hline 10 & $4-\mathrm{NO}_{2} \mathrm{C}_{6} \mathrm{H}_{4}$ & 9.5 & $4 j$ & 90 & $221-222$ & 222 & $11^{\mathrm{b}}$ \\
\hline 11 & 4- $\mathrm{CH}_{3} \mathrm{C}_{6} \mathrm{H}_{4}$ & 7.0 & $4 k$ & 90 & $218-219$ & $217-218$ & $11^{\mathrm{b}}$ \\
\hline 12 & 4- $\mathrm{BrC}_{6} \mathrm{H}_{4}$ & 9.0 & 41 & 90 & 233 & $234-236$ & 18 \\
\hline 13 & $4-\mathrm{FC}_{6} \mathrm{H}_{4}$ & 9.0 & $4 m$ & 75 & 225 & $224-226$ & 18 \\
\hline 15 & $3-\mathrm{ClC}_{6} \mathrm{H}_{4}$ & 8.0 & 40 & 80 & $182-183$ & $183-184$ & $11^{\mathrm{b}}$ \\
\hline 16 & 4- $\mathrm{CH}_{3} \mathrm{OC}_{6} \mathrm{H}_{4}$ & 7.0 & $4 p$ & 82 & $244-245$ & $242-245$ & 18 \\
\hline 17 & $2-\mathrm{CH}_{3} \mathrm{OC}_{6} \mathrm{H}_{4}$ & 7.0 & $4 q$ & 86 & $186-188$ & $190-191$ & 18 \\
\hline
\end{tabular}

ready availability, easy handling, cost effectiveness and remarkably low toxicity with most of the recently reported catalysts.

\section{Spectral data for selected compounds}

3,3,6,6-Tetramethyl-9-benzene-1,8-dioxo-octahydroxanthene (4a): IR (KBr, $\left.v_{\max }, \mathrm{cm}^{-1}\right)$ : 3154, 1668, 1356, 1274, 1201, 1198, 1138, 867. ${ }^{1} \mathrm{H}$ NMR $\left(300 \mathrm{MHz}, \mathrm{CDCl}_{3} \delta\right.$ ppm): $0.98\left(\mathrm{~s}, 6 \mathrm{H}, 2 \mathrm{CH}_{3}\right), 1.12\left(\mathrm{~s}, 6 \mathrm{H}, 2 \mathrm{CH}_{3}\right) 2.20(\mathrm{dd}, 4 \mathrm{H}$, $\left.2 \mathrm{CH}_{2}\right), 2.43\left(\mathrm{~s}, 4 \mathrm{H}, 2 \mathrm{CH}_{2}\right), 4.70(\mathrm{~s}, 1 \mathrm{H}, \mathrm{CH}), 6.74(\mathrm{~m}, 2 \mathrm{H}$, ArH), 6.95(m,3H, ArH); EI MS (m/z): $350\left(\mathrm{M}^{+}\right)$.

3,3,6,6-Tetramethyl-9-(4-chlorophenyl)-1,8-dioxooctahydroxanthene (4b): IR $\left(\mathrm{KBr}, \mathrm{v}_{\max }, \mathrm{cm}^{-1}\right)$ : 3086, 2989 , 1689, 1664, 1640, 1617, 1497, 1366, 1194, 1142, 1121, 1094, 1021, 846. ${ }^{1} \mathrm{H} \mathrm{NMR}\left(\mathrm{CDCl}_{3}, 300 \mathrm{MHz}, \delta \mathrm{ppm}\right): 0.88(\mathrm{~s}, 6 \mathrm{H}$,

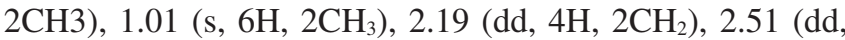
$\left.4 \mathrm{H}, 2 \mathrm{CH}_{2}\right), 4.72(\mathrm{~s}, 1 \mathrm{H}, \mathrm{CH}), 7.52-8.10(\mathrm{~m}, 4 \mathrm{H}, \mathrm{ArH})$; EI MS $(\mathrm{m} / \mathrm{z}): 385(\mathrm{M}+1)$.

3,3,6,6-Tetramethyl-9-(4-nitrophenyl)-1,8-dioxooctahydroxanthene $(\mathbf{4 j})$ : $\mathrm{IR}\left(\mathrm{KBr}, \mathrm{v}_{\max }, \mathrm{cm}^{-1}\right)$ : 3081, 2957, 1666, 1641, 1542, 1492, 1368, 1219, 1170, 1145, 1121, 822, 748. ${ }^{1} \mathrm{H} \mathrm{NMR}\left(\mathrm{CDCl}_{3}, 300 \mathrm{MHz}, \delta \mathrm{ppm}\right) 0.96\left(\mathrm{~s}, 6 \mathrm{H}, 2 \mathrm{CH}_{3}\right)$,

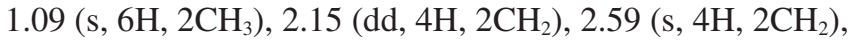
4.48 (s, 1H, CH), 7.16-7.26 (m, 4H, ArH); EI MS (m/z): 396 $(\mathrm{M}+1)$.

3,3,6,6-Tetramethyl-9-(4-bromophenyl)-1,8-dioxooctahydroxanthene (4l): $\mathrm{IR}\left(\mathrm{KBr}, \mathrm{v}_{\max }, \mathrm{cm}^{-1}\right)$ : 3442, 2932, $1660,1585,1362,1274,1201,1138,1047,694,572 .{ }^{1} \mathrm{H}$ NMR (300 MHz, $\left.\mathrm{CDCl}_{3}, \delta \mathrm{ppm}\right), 0.99\left(\mathrm{~s}, 6 \mathrm{H}, 2 \mathrm{CH}_{3}\right) ; 1.11(\mathrm{~s}, 6 \mathrm{H}$, $\left.2 \mathrm{CH}_{3}\right) ; 2.10-2.23$ (q, $\left.4 \mathrm{H}, 2 \mathrm{CH}_{2}\right) ; 2.42$ (s, $\left.4 \mathrm{H}, 2 \mathrm{CH}_{2}\right) ; 4.63$ (s, $1 \mathrm{H}, \mathrm{CH}) ; 7.12-7.23$ (m, 4H, Ar); EI MS (m/z): $429\left(\mathrm{M}^{+}\right)$.

3,3,6,6-Tetramethyl-9-(pyridine-2yl)-1,8-dioxooctahydroxanthene $(4 \mathrm{n})$ : IR $\left(\mathrm{KBr}, \mathrm{v}_{\max }, \mathrm{cm}^{-1}\right)$ : 3305,1685 , 1543, 1011, 874. ${ }^{1} \mathrm{H}$ NMR (300 MHz, $\left.\mathrm{CDCl}_{3}, \delta \mathrm{ppm}\right): 0.96$ (s, $\left.6 \mathrm{H}, 2 \mathrm{CH}_{3}\right) 1.12\left(\mathrm{~s}, 6 \mathrm{H}, 2 \mathrm{CH}_{3}\right), 2.25\left(\mathrm{dd}, 4 \mathrm{H}, 2 \mathrm{CH}_{2}\right) 2.54(\mathrm{~s}$, $\left.4 \mathrm{H}, 2 \mathrm{CH}_{2}\right), 4.71(\mathrm{~s}, 1 \mathrm{H}, \mathrm{CH})$ 7.35-7.92 (m, 4H, Py); EI MS $(\mathrm{m} / \mathrm{z}): 352(\mathrm{M}+1)$.

\section{Conclusion}

A practical and new procedure is developed for the synthesis of 1,8-dioxo-octahydroxanthene derivatives using $\mathrm{Cu}\left(\mathrm{NO}_{3}\right)_{2} \cdot 3 \mathrm{H}_{2} \mathrm{O}$ as catalyst. The present protocol has several advantages, mild reaction conditions, readily available, inexpensive catalyst, easy handling, excellent yields, greater selectivity, operational and experimental simplicity. Study of wide range of structurally divergent aldehydes we believe that, $\mathrm{Cu}\left(\mathrm{NO}_{3}\right)_{2} \cdot 3 \mathrm{H}_{2} \mathrm{O}$ catalyzed methodology will definitely be a valuable addition to the existing process in the field of synthesis of 1,8-dioxo-octahydroxanthene derivatives.

\section{ACKNOWLEDGEMENTS}

The author thanks Head, Department of Chemistry Dr. Rita for her cooperation and Jazan University, for giving an opportunity to continue the research work.

\section{REFERENCES}

1. J. Wichmann, K. Bleicher, E. Vieira, T. Woltering, F Knoflac and V. Mutel, Farmaco, 57, 989 (2002).

2. S. Chatterjee, M. Iqbal, J.C. Kauer, J.P. Mallamo, S. Senadhi and S. Mallya, Bioorg. Med. Chem. Lett., 6, 1619 (1996).

3. (a) Y. Hamada, F. Matsuura, M. Oku, K. Hatano and T. Shioiri, Tetrahedron Lett., 388961 (1997); (b) S. Hillebrand, J. Bruckmann, C. Kruger and M.W. Haenel, Tetrahedron Lett., 36, 75 (1995); (c) G. Malaise, L. Barloy and J.A. Osborn, Tetrahedron Lett., 42, 7417 (2001).

4. (a) S. Hatakeyma N. Ochi, H. Numata and S. Takano, J. Chem. Soc. Chem. Commun., 1202 (1988) and references cited therein; (b) G.M. Cingolant and M. Pigini, J. Med. Chem., 12, 531 (1988).

5. (a) C.N. O'Callaghan and T.B.H. McMurry, J. Chem. Res. Synop., 214 (1995); J. Chem. Res. Miniprint, 1448 (1995) and references cited therein; (b) B. Mirza and S.S. Samiei, Asian J. Chem., 24, 1101 (2012).

6. (a) J. Robak and R.J. Greglewski, Pol. J. Pharmocol., 48, 55 (1996); (b) H.K. Wang, S.L. M.Natschke and K.H. Lee, Med. Res. Rev., 17, 367 (1997); (c) A.V. Rukavishnikov, M.P. Smith, G. Birrell, B. Keana and O.H. Griffith, Tetrahedron Lett., 39, 6637 (1998).

7. E.C. Horning and M.G. Horning, J. Org. Chem., 11, 95 (1946).

8. J.P. Bacci, A.M. Kearney and D.L. Vranken, J. Org. Chem., 70, 9051 (2005).

9. K. Singh, J. Singh and H. Singh, Tetrahedron, 52, 14273 (1996).

10. A. Davoodnia, A.Z. Bidaki and H. Behmadi, Chin. J. Catal., 33, 1797 (2012). 
11. (a) T.S. Jin, J.S. Zhang, A.Q. Wang and T.S. Li, Ultrason. Sonochem., 13, 220 (2006); (b) H.N. Karade, M. Sathe and M.P. Kaushik, Arkivoc., 252 (2007); (c) S. Kantevari, R. Bantu and L. Nagarapu, J. Mol. Catal. A, 269, 53 (2007)

12. A. Ilangovan, S. Malayappasamy, S. Muralidharan and S. Maruthamuthu, Chem. Cent. J., 5, 81 (2011).

13. A. Ilangovan, S. Muralidharan, P. Sakthivel, S. Malayappasamy, S. Karuppusamy and M.P. Kaushik, Tetrahedron Lett., 54, 491 (2013)

14. R.H. Wang, C. Bin, W.T. Zhang and H.G. Fan, Synth. Commun., 40, 1867 (2010)

15. M. Dabiri, S.C. Azimi and A. Bazgir, Chem. Papers, 62, 522 (2008).

16. G.I. Shakibari, P. Mirzaei and A. Bazgir, Appl. Catal., 325, 188 (2007)

17. B. Das, P. Tirupati, K.R. Reddy, B. Ravikanth and L. Nagarapu, Catal. Commun., 8, 535 (2007).

18. G.H. Mahdavania, J. Iran. Chem. Res., 1, 11 (2008).

19. S. Kokkirala, N.M. Sabbavarapu and V.D.N. Yadavalli, Eur. J. Chem., 2, 272 (2011)

20. D. Shi, Y. Lu, Z. Wang and G. Dai, Synth. Commun., 30, 713 (2000).

21. T.S. Jin, J.S. Zhang, J.C. Xiao, A.Q. Wang and T.S. Li, Synlett., 866 (2004).

22. S.K. Mohamed, A.A. Abdelhamid, A.M. Maharramov, A.N. Khalilov, A.V. Gurbanov and M.A. Allahverdiyev, J. Chem. Pharm. Res., 4, 955 (2012).
23. A. Zare, M. Mokhlesi, A. Hansaninejad and T.H. Zahed, E-J. Chem., 9 (2012).

24. M. Kargar, R. Hekmatshoar and A.J. Mostashari, J. Iran. Chem. Soc., 9, 483 (2012)

25. X. Fan, X. Hu, X. Zhang and J. Wang, Can. J. Chem., 16, 83 (2005).

26. G. Song, B. Wang, H. Luo and L. Yang, Catal. Commun., 8, 673 (2007)

27. P. Anastas, T. Williamson, Green Chemistry, Frontiers in Benign Chemical Synthesis and Procedures; Oxford Science Publications; Oxford, pp. 166-177 (1998)

28. (a) V. Ravi, A. Nasreen, E .Ramu and S.R. Adapa, Tetrahedron Lett., 48, 69 (2007); (b) V. Ravi, A. Nasreen and S.R. Adapa, Can. J. Chem., 85, 1 (2007) and references cited therein; (c) R. Varala, E. Ramu, N. Sreelatha and S.R. Adapa, Tetrahedron Lett., 47, 877 (2006) and references cited therein; (d) R. Varala and S.R. Adapa, Org. Proc. Res. Dev., 9, 853 (2005); (e) R. Varala, N. Sreelatha and S.R. Adapa, Synlett., 1549 (2006); (f) R. Varala, E. Ramu, N. Sreelatha and S.R. Adapa, Synlett., 1009 (2006); (g) R. Varala, E. Ramu and S.R. Adapa, Synthesis, 3825 (2006); (h) R. Varala, E. Ramu, P.V. Kumar and S.R. Adapa, Chin. J. Chem., 24, 807 (2006); (i) R. Varala, N. Sreelatha and S.R. Adapa, Bull. Korean Chem. Soc., 27, 1079 (2006); (j) M.M. Alam, R.Varala, E. Ramu and S.R. Adapa, Lett. Org. Chem., 3, 187 (2006); (k) R. Varala, E. Ramu and S.R. Adapa, Bull. Chem. Soc. (Japan), 79, 140 (2006); (1) R. Varala, N. Sreelatha and S.R. Adapa, J. Org. Chem., 71, 8283 (2006). 